\title{
AGRICULTURE'S IMPACT FOR THE ECONOMY: INTER-INDUSTRY LINKAGES AND MULTIPLIER EFFECTS
}

\begin{abstract}
Giedrė DZEMYDAITÉ, Department of Economic Policy, Faculty of Economics and Business Administration, Vilnius University, Address: Saulètekio av. 9, II bld., Vilnius, Lithuania, giedre.dzemydaite@ef.vu.lt

The role of agriculture sector is understood as being vital for economic development and well being of rural areas. Common agriculture policies in the EU and production shocks in agriculture sector reflect in production changes that causes direct and indirect effects for other industries development in the region, as well as, households' income. This paper aimed to evaluate agriculture sector's direct and indirect impacts for the economy by analyzing sectoral linkages and multiplier effects. Input-output analysis techniques were applied. Both output and income multipliers were evaluated. This paper supports the idea that agriculture sectors were more multiplying the economy than other sectors on average. This sector remains important catalyst of the economy, especially while taking into account development challenges in rural areas.
\end{abstract}

Keywords: agriculture, input-output analysis, multiplier effect, inter-industry linkages, networks

\section{INTRODUCTION}

Even though the relative size of agriculture sector is comparatively low in more economically developed countries, the role of agriculture remains vital for economic development and well being of rural areas. Agricultural has shifted emphasis away from commodity support to diversification production practices and rural development policy in more developed countries (Diakosavvas, 2006; Bonfiglio et al. 2016). Agriculture production tends to change because of various demand shocks in global economy and as well as changes in Common agriculture policies (CAP) in the European Union. Impacts of reforms can be expected to be felt beyond the agricultural sector and affect entire regional economy (Mattas et al., 2011). The delivery of policy and consequently associated economic shocks differ according to local resources, the effectiveness of governance and the nature of regional economic structure (Watts et al., 2009).

This paper focuses on the nature of regional economic structure and ties to figure out how the demand changes in agriculture are felt in other sectors. It aims to evaluate agriculture sector's direct and indirect impacts for the economy by analyzing inter-industry linkages and multiplier effects.

There are few researches of agricultural sector's impact on Lithuanian economy. The most studies are focused on evaluating direct impact of various policy instruments on agricultural activity, its intensity and income rather than its impact for overall regional economic development and demand changes in other sectors. For example, Kripaitis et al. (2014) analyzed direct payments impact for employment and spending in agricultural sector; Vitunskiene and Baltusiene (2013) measured farmers income before and after joining the EU; Volkov and Drozdz (2016) evaluated the extent to which the CAP 2004-2013 direct payment scheme has contributed to the changes of viability and economic attractiveness of different types of farming in Lithuania; Ferto and Stagliene (2016) investigated the effects of agricultural subsidies on income variability of Lithuanian dairy farms suggesting that agricultural subsidies have positive impact on income risk. Indirect effects of agriculture sector to other sectors were not involved in recent studies.

Impact of agriculture's policy for economic development was measures in diverse research papers abroad. Indirect effects of demand changes in agriculture sector were involved in part of the studies. For example, Giannakis and Efstratoglou (2011) measured CAP impact and multiplier effects in Greece. Bonfiglio et al. (2016) applied geographically broader approach of CAP impact for economy. In this paper they assessed spill over effects produced by CAP payments across the European Union regions (NUTS3) on the distribution of gross domestic product and employment in rural areas and more economic developed areas. They supported the idea that the impacts generated by the CAP across the space do not only depend on the initial allocation of funds but also on inter-sectoral and interregional linkages. This analysis implied that even a radical reallocation of funds might contribute to reducing regional imbalances, as it is less redistributive than expected.

According to that, this paper analyzes inter-industry linkages in Lithuanian economy. It does not focuses on a particular policy instrument or its evaluation, but rather on nature of the economy, inter-industry networks and multiplier

Copyright (C) 2017 The Authors. Published by Aleksandras Stulginskis University. This is an open-access article distributed under the terms of the Creative Commons Attribution License (CC-BY 4.0), which permits unrestricted use, distribution, and reproduction in any medium, provided the original author and source are credited. 
effects, and tries to give insights what would be the impact for overall economy if agriculture production volumes changes that is supposed to be a consequence of demand shocks or agriculture policy instruments.

\section{RESEARCH METHODS}

Input-output analysis is recognized as the most suitable quantitative technique for studying the interdependence of production sectors in an economy and identifying major sectors and financial flows between them, over a stated period of time (Giannakis and Efstratoglou, 2011). Input-output tables (IOT) are supposed to offer the most detailed portrait of an economy (Eurostat, 2008). They provide a detailed analysis of the process of production and the use of goods and services (products) and the income generated in that production. In this paper fixed-price Leontief-style input-output (IO) model was applied for the IOT analysis. It is a general equilibrium model. This model has traditionally been used to study the potential of final demand changes in one or more sectors to simulate wider impacts in output throughout the economy. Compared to computable general equilibrium (CGE) models that have also been developed to explore various dimensions of rural economic change at regional or local level, Leontief model is based on constant returns to scale production functions and assumptions related with factor supply (Kilkenny and Partridge, 2009; McGregor et al., 1996; Lindberg et al., 2012). Fixed coefficients of production assume a production function with linear constant returns to scale. Then, homogeneity assumption states that sector uses the same technology for producing goods or services. Finally, perfectly elastic factor supplies refer to ability to increase production volumes as demanded.

Input Output transaction matrix provides a static view of inter-industry linkages within economy at particular time. Information about consumption of intermediate goods and services, final consumption expenditures by government, households, and NGOs, as well as, demand from foreign markets are also represented in the table. This information helps to explain how increase of final demand for a certain goods or services leads to an increase in the inter-industry demand, which in turn leads to increase in the output of the other industries in the region.

Data from WIOD (World input-output database) was analyzed. WIOD give the values of transactions among 35 industries in 40 countries plus the 'Rest of the World' and from these industries to households, governments and users of capital goods in the same set of countries. The database combines detailed information on national production activities and international trade data (Tukker and Dietzenbacher, 2013).

IO tables are often aggregated to facilitate data presentation and management, even though disaggregated tables could give more precise insight about inputs and outputs of smaller sectors (Lindberg et al., 2012). In WIOD, agriculture, forestry and fishing are subdivided into three categories: A01 - Crop and animal production, hunting and related service activities; A02 - Forestry and logging; A03 - Fishing and aquaculture. It is based on International Standard Industrial Classification (Dietzenbacher et al., 2013). This subdivision do not gives information about inputs and outputs of more detailed subsectors such as an animal production, plant propagation or growing of different products. This is one of the limitations of the analysis, as different subsectors could have had a divided influence for the economy and other sectors. According to the data from WIOD, A01 is analyzed in this paper as an aggregated agriculture sector.

The demand-driven IO quantity model applied in this paper has two behavioural assumptions, firstly introduced by Leontief (1936). These assumptions imply that these are no bottlenecks in the region's labor, land, or capital markets. The first states that the supply of output of all sectors with $\mathrm{i}=1, \ldots, \mathrm{N}$, follows the total of the intermediate demands $z_{i j}$ and the total of the final demands $y_{i q}$ for its products:

$$
x_{i}=\sum_{j} z_{i j}+\sum_{q} y_{i q} \text { or in matrix algebra: } \mathbf{x}=\mathbf{Z} \mathbf{i}+\mathbf{Y} \mathbf{i}=\mathbf{Z} \mathbf{i}+\mathbf{y}(1)
$$

where $z_{i j}$ - the deliveries of intermediate products from industry $\mathrm{i}$ to industry $\mathrm{j}$ (with $i, j=1, \ldots, N$ );

$y_{i q}-$ the deliveries of industry $i$ to final demand category q (e.g. consumptions, government, investments, and exports, with $q=1, \ldots, Q)$;

$x_{i}$ - total sales by industry $i$, contains the deliveries of industry i to final demand category $\mathrm{q}$ and the deliveries of intermediate products from industry $i$ to industry $j$.

The second behavioural assumption is that the demand for intermediate inputs $z_{i j}$ and primary inputs $v_{p j}$ is linearly and solely determined by the total output of purchasing industry $j$ :

$$
\begin{gathered}
z_{i j}=a_{i j} x_{j}, \text { for all } i, j, \text { or in matrix algebra: } \mathbf{Z} \mathbf{i}=\mathbf{A} \mathbf{x}(2), \\
v_{p j}=c_{p j} x_{j}, \text { for all } p, j, \text { or in matrix algebra: } \mathbf{V} \mathbf{i}=\mathbf{C} \mathbf{x}(3),
\end{gathered}
$$

where $a_{i j}$-technical coefficients that indicate the amount of intermediate inputs from industry $i$ needed per unit of output of industry $j$

$x_{j}$ - total cost of industry $j$

$v_{p j}$ - primary inputs of category $p$ (i.e., imports, taxes or subsidies, and components of gross value added at market prices) used by industry $j$, with $p=1, \ldots, P$;

$c_{p j}$ - technical coefficients that indicate the amount of primary inputs of category $p$ needed per unit of output of industry $j$.

Analyzing and comparing $z_{i j}$ and $x_{j}$ data allows for analysis of the purchase and cost structure of various sectors, as well as, $z_{i j}$ and $\mathrm{x}_{\mathrm{i}}$ data could give insights into sales structure of each sector. 
Any change in $\mathbf{y}$ will lead to an equally direct change of $\mathbf{I} \Delta \mathbf{y}$ in total output $\mathbf{x}$. It reveals the first round indirect effects on the demand for the intermediate inputs of $\mathbf{A}_{\Delta} \mathbf{y}$ and primary inputs of $\mathbf{C}_{\Delta} \mathbf{y}$. The first round effect on primary inputs will have no further changes in endogenous variables. Differently from primary inputs, the first round effect on intermediate inputs will lead to an equally large backward change in total output, indicated by $\mathbf{I}$. This leads to second round indirect effects in the demand for intermediate and primary inputs of $\mathbf{A}^{\mathbf{2}} \Delta \mathbf{y}$. The third round indirect effects amount to $\mathbf{A}^{\mathbf{3}} \Delta \mathbf{y}$, and so on. Finally, the size of total outputs will be equal to:

where $\mathbf{L}=(\mathbf{I}-\mathbf{A})^{-1}$ reveals output multipliers.

$$
\mathbf{x}=\left(\mathbf{I}+\mathbf{A}+\mathbf{A}^{2}+\mathbf{A}^{3}+\ldots\right) \mathbf{y}=(\mathbf{I}-\mathbf{A})^{-1} \mathbf{y}=\mathbf{L y}(4),
$$

The equilibrium solution for endogenous intermediate and primary inputs could be found by substituting Eq. 4 in Eqs. 2 and 3 as follows:

$$
\begin{gathered}
\mathbf{Z} \mathbf{i}=\mathbf{A}(\mathbf{I}-\mathbf{A})^{-1} \mathbf{y}=\mathbf{A} \mathbf{L} \mathbf{y}(5) \\
\mathbf{v}=\mathbf{V} \mathbf{I}=\mathbf{C}(\mathbf{I}-\mathbf{A})^{-1} \mathbf{y}=\mathbf{C} \mathbf{L} \mathbf{y}(6)
\end{gathered}
$$

Sectors' multipliers, known as output multipliers, could be analyzed from $\mathbf{L}$. $l_{i j}-$ an element of L indicates the direct and indirect need for outputs of industry $i$ per unit of final demand for products of industry $j$. The column sums of $\mathbf{L}$ indicate the economy-wide total output effect of the same unit of final demand. Also income multipliers could be evaluated from matrix $\mathbf{C ~} \mathbf{L}$ in Eq. 6. If we take $p$ that is related to the total value added or the use of labour, its element $c l_{p j}=\sum_{i} c_{p i} l_{i j}$ indicates the economy-wide direct and indirect income per unit of final demand for products from industry $j$. Such primary multipliers complement insights from output multipliers.

\section{RESEARCH RESULTS}

In Lithuanian economy agricultural sector (A01) tends to use intermediate goods from 43 sectors out of 54. It reveals wide range of inter-industry linkages. For the comparison, other sectors that are more related to the rural activity, such as a forestry sector (A02) and a fishing and aquaculture (A03), tend to consume intermediate goods from just few local sectors, respectively, A02 from 14 sectors and A03 from 5 sectors. This tendency supports the idea that comparatively diversified agriculture sector in Lithuania is a sufficient consumer of intermediate goods in Lithuanian economy. The growth or decline of this sector tends to affect a wider set of other industries in the economy even though the intensity of purchases from other sectors could be differentiated.

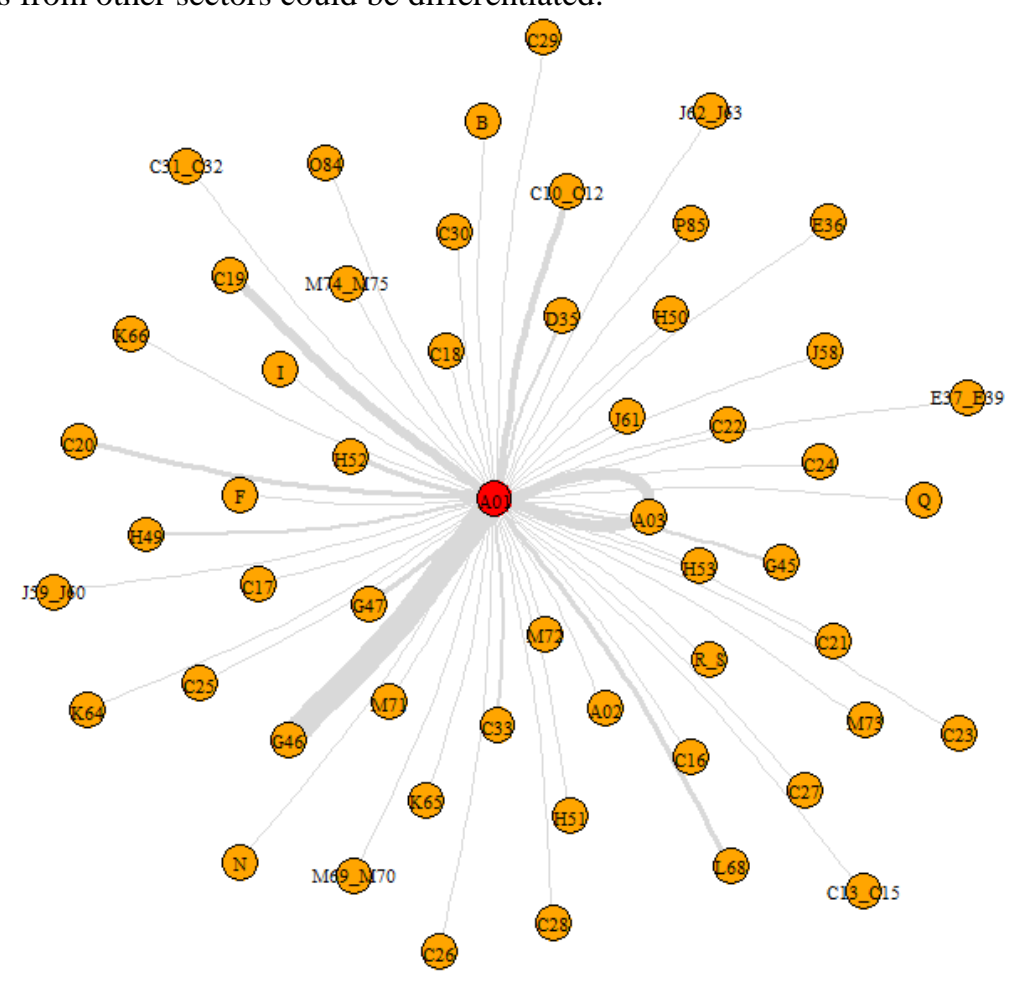

Figure 1. Intersectoral linkages of agriculture sector (A01) and other sectors in Lithuanian economy (a direct effect), 2014. Source: WIOD, author's calculations

Agriculture sector's inputs structure from the other Lithuanian sectors is visualized in figure 1. The wider lines reveal more intense purchases of intermediate goods from other industries. Agriculture sector tends to purchase intermediate goods mostly from 5-6 sectors: wholesale trade, except of motor vehicles and motorcycles (C46) - with technical coefficient $a_{29,1}=0.071$; crop and animal production, hunting and related service activities (A01) - with technical coefficient $a_{1,1}=0.033$; manufacture of coke and refined petroleum products (C19) - with technical coefficient $a_{10,1}=0.071$; manufacture of food products, beverages and tobacco products (C10_C12) - with technical coefficient $a_{5,1}=0.021$; manufacture of chemicals and chemical products (C20) - with technical coefficient $a_{11,1}=0.017$; and real estate activities 
(L68) - with technical coefficient $a_{44,1}=0.015$. Inputs from other sectors are of comparatively low intensity. These numbers reveals agriculture sectors inputs structure and industries mostly affected by this sector. It also gives a primary view from what channels direct and indirect effects are induces in the economy.

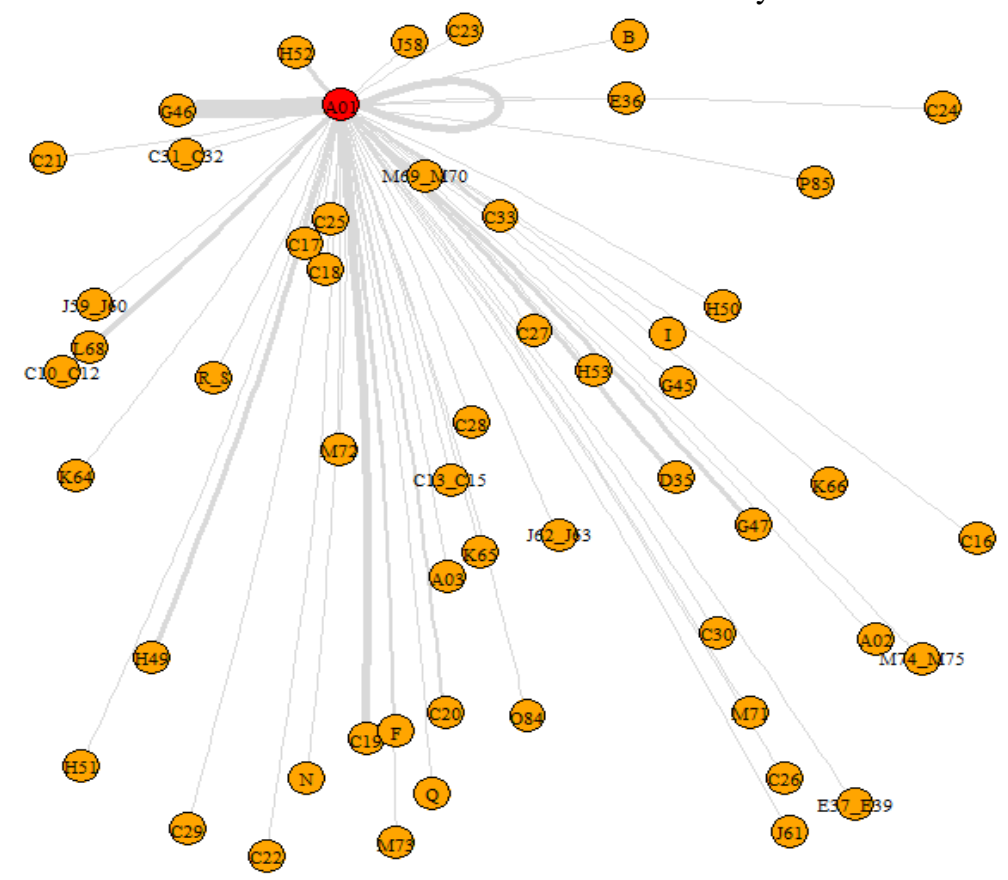

Figure 2. Output multipliers of agriculture sector (A01) $\left(l_{i 1}\right.$, for $\left.i=1, \ldots, N\right), 2014$. Source: WIOD, author's calculations

Figure 1 implies direct effects of production changes in agriculture sector to other sectors in Lithuania economy. Increase demand for intermediate goods in various sectors implies supplementary effects. For example, if G46 sector has to produce more intermediate goods for an agriculture sector, it has also to purchase goods for the production and it causes induced effects. According to that output multipliers are evaluated to find direct and indirect effects. Output multipliers reveal the economy-wide total output effect. For A01 an output multiplier is 1.45. It implies that increase in agriculture output by 1 unit generates 1.45 units in economy-wide total output. Compared to other sectors in the economy, A01 output multiplier is higher than the average of 1.36 .

It is also important to look deeper into the structure of output multiplier and related sectors. Figure 2 reveals which sectors are mostly affected by production changes in A01 both directly and indirectly. When we analyze the indirect impact, all the sectors in the economy are affected by agriculture directly or indirectly to different extend. The tendencies remain very common to figure 1 - wholesale (G46), agriculture (A01), and manufacture of coke and refined petroleum products (C19) are mostly affected by demand and production changes in agriculture sector.

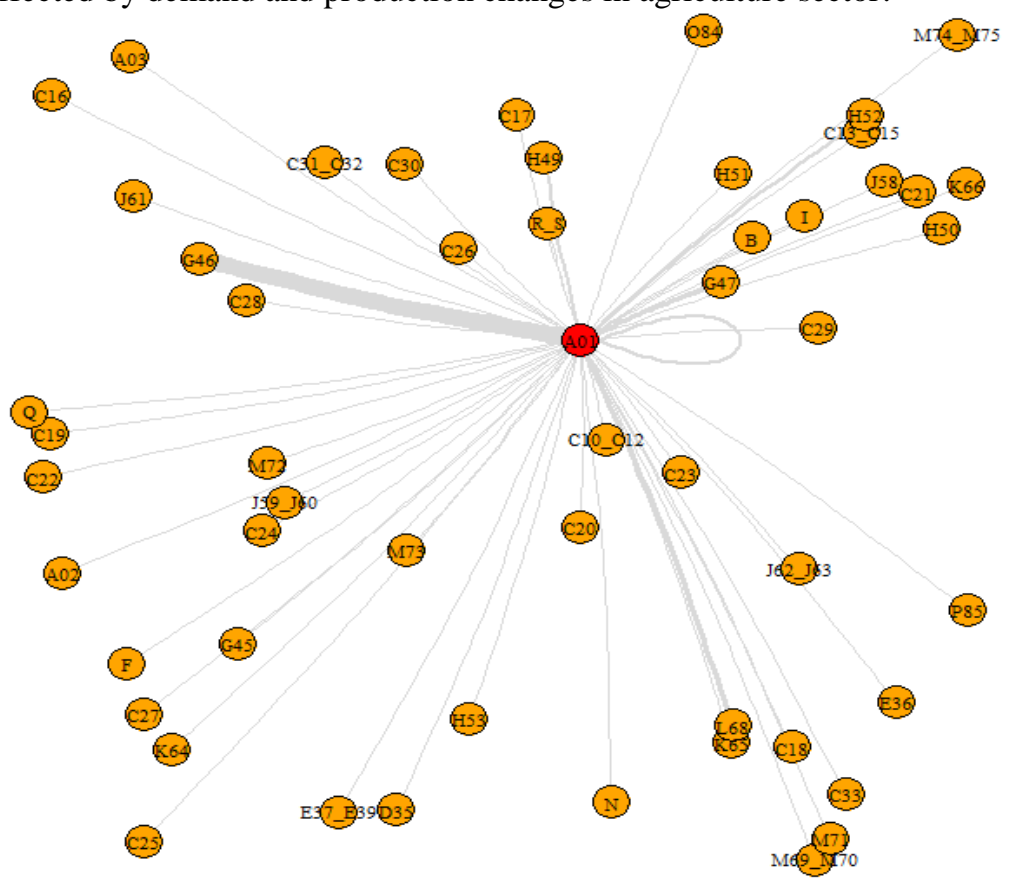

Figure 3. Indirect income multiplier effects by agriculture (A01) to other sectors, 2014. Source: WIOD, author's calculations In figure 3 indirect income multipliers are visualized. The calculation of income multipliers are related with the level of output multipliers in different sectors. It reveals how the changes in agricultural output affect income of 
companies' workers and owners in the economy as a whole and in different industries. Value added data from IOT is analyzed. Value added is supposed to be a primary input that implies income levels. Technical coefficient of this primary input is $c_{5,1}=0,365$. Income multiplier is 1.641 . It indicates economy-wide direct and indirect income per unit of final demand for products from A01. Compared to the average income multiplier of 1.443 it is one of the highest in Lithuanian economy. A01 sector tends to affect income mostly for wholesale (G46), retail trade (G47) and real estate (L68) companies' workers and owners (Figure 3) that is related to the output changes in these sectors.

\section{CONCLUSIONS AND DISCUSSIONS}

Agriculture remains one of the most important sectors of less inhabitant rural areas, being vital for rural development and well being of these territories. Agriculture production tends to change because of various demand shocks in global economy and changes in policies. Impacts of reforms can be expected to be felt beyond the agricultural sector and affect entire regional economy. The delivery of policy and consequently associated economic shocks differ according to local resources, the effectiveness of governance and the nature of regional economic structure.

The aim of this paper was to evaluate agriculture sector's economy-wide direct and indirect impact by analyzing inter-industry linkages and multiplier effects. There are little studies of an agricultural sector's impact on Lithuanian economy. The most studies were focused on evaluating a direct impact of various policy instruments on agricultural activity rather than economy-wide effects that was involved in this paper.

Fixed-price Leontief-style input-output model was applied for the input-output analysis. Most recent data from WIOD was analyzed. Output and income multipliers were evaluated. It supported the idea that agriculture remained an important catalyst of income changes, especially taking into account development challenges in rural areas. This paper analyzed how demand changes supposed to affect whole country's economy rather than particular rural region. In rural territorial breakdown, i.e. as analyzed in Giannakis and Efstratoglou (2011), results could differ. Tourism or trade could be more multiplying if smaller territorial breakdown is selected. This type of analysis did not reflect the possible impact for other rural or urban areas or country as a whole. In our study, agriculture sector tended to be one of the most multiplying the overall country's economy. In its input structure it was related with a wide range of sectors. It was purchasing intermediate goods from 43 sectors out of 54, while indirectly affecting production of all the sectors in the Lithuanian economy. Both, an economy-wide output multiplier and income multiplier of agriculture, were higher than the country's average. An output multiplier was equal to 1.45 and an input multiplier was 1.641 , while the average multipliers were 1.36 and 1.443 respectively.

While looking at the research results from the political perspective, each 7 years before the beginning of the new multiannual financial framework of the EU there are a lot of discussions and political debates for choosing the most important political priorities for the EU investment and spending. Common agriculture policy remains one of the most significant part of the EU budget, but it is all the time a discussion if this policy will stay as an important part of the EU budget in the future and if politicians will keep seeing benefits of this policy between the other and new rising issues and priorities, such as a migration crisis, reduced financial resources because of the Brexit, an aging society, the forth industrial revolution and others. According to that, more scientific arguments to evaluate the role of this policy are needed. So this study was focused on revealing some aspects of the impact of the Common agriculture policy in a broader economic perspective though a sector breakdown. Conducted research revealed that agriculture sector was multiplying overall economy by having a lot of inter-industry linkages with local producers and services business inside the country rather than other sectors in Lithuanian economy.

However, it is a discussion question if money that comes from agriculture sector's production demand keeps circulating in rural areas or moving more to countries' urban areas. When we analyzed what was the distribution of direct and indirect effect to different industries, the growth of agriculture sector supposed to have highest induced effects on income growth in a wholesale, retail, and real estate. Input-output tables do not include information if these sectors, mostly affected by agriculture, were based in rural or urban areas. So it remains a question for a discussion if induced income and output effects contributes to rural development more than urban and to what extent. According to Bonfiglio et al. (2016) who analyzed CAP expenditure spill-over effects in a smaller territorial breakdown of the EU (NUTS3), the degree of urbanization tended to raise the share of extra-local effects. Therefore, despite fund distribution in favor of rural and intermediate regions, GDP effects supposed to be more equally distributed and, in fact, higher in urban regions.

\section{REFERENCES}

1. Bonfiglio, A., Camaioni, B., Coderoni, S., Esposti, R., Pagliacci, F., Sotte, F. 2016. Where does EU money eventually go? The distribution of CAP expenditure across the European space. Empirica, Vol. 43, Iss. 4, pp. $693-727$. https://doi.org/10.1007/s10663-016-9354-2

2. Diakosavvas, D. (ed.) 2006. The Development Dimension: Coherence of Agricultural and Rural Development Policies (Paris: OECD, 2006).

3. Dietzenbacher, E., Los, B., Stehrer, R., Timmer, M., Gaaitzen de Vries. 2013. The Construction of World Input-Output Tables in the WIOD Project. Economic Systems Research, Vol. 25, Iss. 1, pp. 71-98. https://doi.org/10.1080/09535314.2012.761180

4. Giannakis, E.; Efstratoglou, S. 2011. An input-output approach in assessing the CAP reform impact of extensive versus intensive farming systems on rural development: the case of Greece. Agricultural Economics Review, Vol. 12, Iss. 1, pp. 81-90. 
5. Eurostat. 2009. Eurostat Manual of Supply, Use and Input-Output Tables. Economics and Finance. Methodologies and Working Papers. ISSN 1977-0375

6. Ferto, I., Stagliene, A. 2016. Effects of agricultural subsidies on income risk in Lithuanian dairy farms. Management Theory and Studies for Rural Business and Infrastructure Development, Vol. 38, Iss. 4, pp. 351-358. https://doi.org/10.15544/mts.2016.27

7. Kilkenny, M. and Partridge, M. D. 2009. Export sectors and rural development. American Journal of Agricultural Economics, Vol. 91, Iss. 4, pp. 910-929. https://doi.org/10.1111/j.1467-8276.2009.01320.x

8. Kripaitis, R., Namiotko, V., Galnaitytė, A., Jedik, A. 2014.The impact of direct payments on the activity results of agricultural producers. Management Theory and Studies for Rural Business and Infrastructure Development, Vol. 36, Iss. 2, pp. 336-345. https://doi.org/10.15544/mts.2014.030

9. Lindberg, G., Midmore, P. and Surry, Y. 2012. Agriculture's Inter-industry Linkages, Aggregation Bias and Rural Policy Reforms. Journal of Agricultural Economics, Vol. 63, pp. 552-575. https://doi.org/10.1111/j.1477-9552.2012.00354.x

10. Mattas, K., Arfini, F., Midmore, P., Schmitz, Mand Surry, Y. 2011. Impacts of CAP reform on rural employment: a multi-country, multi-modelling cross-country approach. Ch 14 in OECD', in Disaggregated Impacts of CAP Reforms: Proceedings of an OECD Workshop, Paris: OECD Publishing, 2011, pp. 251-264.

11. McGregor, P. G., Swales, J. K. and Yin, Y. P. A. (1996). Long-run interpretation of regional input-output analysis', Journal of Regional Science, Vol. 36, Iss. 3, pp. 479-500. https://doi.org/10.1111/j.1467-9787.1996.tb01113.x

12. Partridge, M. D., Rickman D. S. 2010. Computable General Equilibrium (CGE) Modelling for Regional Economic Development Analysis. Regional Studies, Vol. 44, Iss. 10, pp. 1311-1328. https://doi.org/10.1080/00343400701654236

13. Tukker, A., Dietzenbacher, E. 2013. Global Multiregional Input-Output Frameworks: and Introduction and Outlook. Economic Systems Research, Vol. 25, No. 1, pp. 1-19. https://doi.org/10.1080/09535314.2012.761179

14. Vitunskienė, V., Baltušienè, J. 2013. Žemès ūkio subsidijų ir socialinių pašalpų poveikis žemdirbių namų ūkių pajamoms Lietuvoje. Ekonomika ir vadyba: aktualijos ir perspektyvos, Vol. 4, Iss. 32, pp. 73-85.

15. Volkov, A., Droždz, J. 2016. Evaluating Impact of the Common Agricultural Policy 2004-2013 Direct Payment Scheme on Economic Sustainability of Agriculture in Lithuania. Problems of Agricultural Economics, Vol. 3, Iss. 348, pp. 93-105. https://doi.org/10.5604/00441600.1218280

16. Watts, D. C. H., Ilbery, B.and Maye, D. 2009. Implementing pillar II of the Common Agricultural Policy in England: Geographies of the rural enterprise scheme and processing and marketing grant. Land Use Policy, Vol. 26, Iss. 3, pp. 683-694. https://doi.org/10.1016/j.landusepol.2008.09.004 